\title{
Penyusunan Bangunan Bata Candi Gayatri (Kajian Teknologi Berdasarkan Analisis Laboratorium)
}

\section{Ni Komang Ayu Astiti}

Keywords: chemical, composition, brick, clay, construction, temple

\section{How to Cite:}

Astiti, N. K. A. (2003). Penyusunan Bangunan Bata Candi Gayatri (Kajian Teknologi Berdasarkan Analisis Laboratorium). Berkala Arkeologi, 23(1), 63-74. https://doi.org/10.30883/jba.v23i1.861

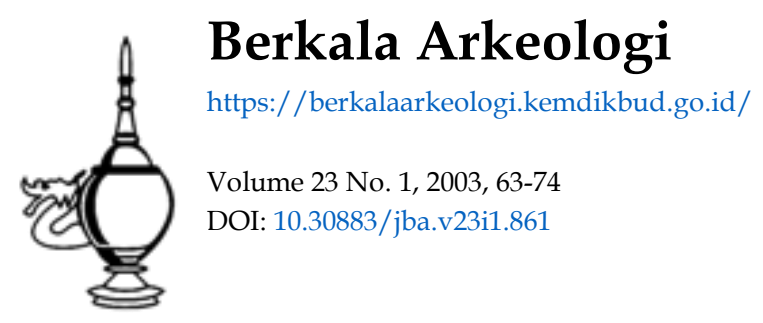

\section{c) (7)(2)}

This work is licensed under a Creative Commons Attribution-NonCommercial-ShareAlike 4.0 International License. 


\title{
PENYUSUNAN BANGUNAN BATA CANDI GAYATRI \\ (Kajian Teknologi Berdasarkan Analisis Laboratorium)
}

\author{
Ni Komang Ayu Astiti
}

1

endahuluan

Di Jawa Timur banyak ditemukan bangunan-bangunan kuno peninggalan nenek moyang bangsa Indonesia yang masih berdiri kokoh walaupun kondisinya sudah tidak utuh lagi atau telah mengalami pemugaran. Sisa-sisa bangunan ini sebagian besar merupakan sisa-sisa pemukiman masa lalu yaitu berupa bangunan yang dipergunkan untuk sarana pemujaan ataupun tempat tinggal. Sisa-sisa bangunan yang bersifat religi (keagamaan) yaitu berupa bangunan-bangunan candi yang berasal dari masa klasik yang menggunakan bata merah sebagai unsur bangunan utamanya. Di samping berupa bangunan candi pemanfatan bata merah pada masa ini di sekitar candi juga ditemukan dalam bentuk struktur-struktur pondasi. Struktur pondasi ini belum diketahui secara pasti apakah sisa bangunan berupa tempat tinggal (pemukiman) bagi pemuja Candi Gayatri atau masih merupakan bagian dari bangunan candi sendiri. Di tengah sungai DAS Berantas tepatnya di perbatasan antara Desa Srikaton Kecamatan Ngantru dengan Desa Bulusari Kecamatan Kedungwaru juga ditemukan struktur pondasi yang terbuat dari bata merah. Di lihat dari sampel bata yang ada maka bata yang ditemukan pada struktur pondasi ini berbeda dengan bata yang ditemukan pada struktur pondasi yang ada di sekitar candi. Perbedaan ini terutama terletak pada susunan bata karena pada bata di sini terdiri dari dua lapis dengan warna bahan yang berbeda. Menurut keterangan penduduk setempat struktur pondasi ini merupakan bekas bangunan air yaitu berupa dam atau waduk air. Strukturstruktur pondasi dari bata merah yang ditemukan di daerah Boyolangu khususnya di sekitar candi Gayatri ini sebagian besar tertimbun oleh tanah yang letaknya berada di jalan raya, pekarangan rumah penduduk di sekitar candi. Bangunan-bangunan candi yang terdapat di daerah Tulung Agung ini letaknya menyebar dan kondisinya sudah tidak utuh lagi karena bangunan ini ada yang sudah runtuh dan tidak terawat sehingga susunan batanya tidak teratur lagi, tetapi hanya tersisa bagian pondasin dan badan seperti Candi Joho, Candi Sumberingin, Candi Pesanggrahan serta Candi Gayatri.

Candi Gayatri yang terletak di desa Boyolangu sampai saat ini masih terawat rapi walaupun hanya berupa pondasi dan bagian badan candi. Unsur utama bangunan ini adalah bata merah di samping menggunakan batu andesit yang berupa umpak-umpak berbentuk trapesium. Bata merah yang dipergunakan untuk bangunan candi ini mempunyai bentuk dan ukuran yang bervariasi dan tersusun rapi. Antara bata yang satu dengan bata yang lainnya ada sebagian yang mempergunakan lepa sebagai bahan perekat. Bentuk dan ukuran bata yang dipergunakan disesuaikan dengan kebutuhan bangunan, seperti bata pada pondasi ditemukan lebih dari dua ukuran dan berbeda 
dengan ukuran bata yang ditemukan pada bata yang digunakan pada bagian badan candi. Selain bentuk bata dengan ukuran persegi panjang juga ditemukan bata dengan bentuk segitiga atau setengah lingkaran yang dipergunakan pada bagian-bagian tertentu. Secara fisik ukuran dan bentuk bata yang bervariasi ini dapat dengan mudah di ketahui di lapangan sehingga kontruksi teknologi penyusunan bata pada bangunan candi gayatri masa lalu dapat diketahui. Tetapi apakah pada masa itu dalam pembuatan Candi Gayatri penyusunan bata dari pondasi sampai pada bagian puncak juga dilakukan pemilihan bahan baku dan sengaja dibedakan dengan maksud dan tujuan tertentu ?. Pemilihan bahan baku ini dititikberatkan dengan tujuan untuk kekuatan dan daya tahan pada bagian pondasi untuk menahan beban bangunan candi. $\mathrm{Hal}$ ini diperlukan agar kekuatan pada bagian pondasi lebih tinggi jika dibandingkan dengan bangunan pada bagian atas.. Permasalahan ini timbul karena jika tidak dilakukan pemilihan bahan baku dan perbedaan kualitas bahan bangunan pada bagian bawah (pondasi) dengan bangunan bagian atasnya maka kemungkinan besar bangunan candi Gayatri tidak dapat bertahan lama bahkan sampai ratusan tahun walaupun sudah tidak utuh lagi. Permasalahan ini akan dicoba di jawab dengan menggunakan pendekatan analisis komposisi unsur kimia dan sifat-sifat fisik bahan baku bata di laboratorium terutama dilihat dari teknologi pembuatan bata merah ( dalam hal ini sampel di ambil pada bagian pondasi dan bagian badan) .

\section{A. Gambaran Situs}

Kabupaten Tulung Agung yang merupakan daerah ditemukannya Candi Gayatri berada di antara $7^{\circ} 51^{\prime}-8^{\circ} 18^{\prime \prime}$ Lintang Selatan dan $111^{\circ} 43^{\prime \prime}-112^{\circ} 7^{\prime}$ Bujur Timur dari meridien Jakarta. Daerah ini mempunyai luas sekitar $1000 \mathrm{Km}^{2}$, di bagian timur dan utara berbataskan dengan Kabupaten Trenggalek, di sebelah timur berbataskan dengan Samudra Indonesia. Iklim wilayah ini termasuk dalam iklim katulistiwa (sabana tropik) dengan suhu bulanan rata-rata lebih besar dari $18^{\circ} \mathrm{C}$ dengan suhu tahunan antara $20-30^{\circ} \mathrm{C}$ dan curah hujan setiap tahun antara $1500-2000 \mathrm{~mm}$. Bentang alam Tulung Agung terbagi 3 satuan morfologi yaitu satuan morfologi daratan, satuan morfologi bergelombang lemah dan satuan morfologi kuat.

Candi Gayatri yang terletak di Desa Boyolangu, Kecamatan Boyolangu, Kabupaten Tulung Agug terdiri dari dua bangunan yaitu candi induk dan perwara. Kedua candi tersebut merupakan teras yang di susun dari bata merah. Pada candi induk terdapat arca Prajnaparanita tanpa kepala dan tangan yang terbuat dari batu andesit, pada bagian badan candi juga terdapat umpak batu dari batu andesit, simpul berukuran besar ( $\mathrm{p} \times 1$ ) bawah $70 \times 70 \mathrm{~cm}$, dan tinggi $61 \mathrm{~cm}$. Di samping umpak berukuran besar, pada candi ini juga ditemukan tiga buah umpak yang berukuran lebih kecil dan mempunyai ukuran lingkaran pada bagian atas $30 \mathrm{~cm}$ serta pada bagian bawah $50 \mathrm{~cm}$ dan tinggi $30 \mathrm{~cm}$. Candi Gayatri ini menghadap ke arah barat dan tidak jauh dari sisi bagian barat, selatan dan utara candi ditemukan struktur pondasi yang terbuat dari bata 
merah, dan diperkiraan merupakan suatu bangunan pemukiman. Di sekitar candi ini selain ditemukan struktur-struktur pondasi dari bata merah juga banyak ditemukan adanya fragmen-fragmen tembikar dengan bentuk, warna dan hiasan yang bervariasi serta ditemukan juga tulang dan gigi geraham binatang dalam keadaan terbakar.

Dari bentuk relief candi yang menunjukan adanya relief sisi ganda dari lapik arca yang juga melambangkan bunga teratai, menunjukan adanya unsur-unsur yang bersifat Budhis. Dengan demikian candi gayatri ini berlatar belakang agama Ciwa Budha, suatu pembaharuan yang biasa terjadi pada masa-masa itu di Jawa Timur. Dalam kitab Negarakertagama candi ini disebutkan sebagai tempat pendharmaan istri Raden Wijaya (Ratu Majapahit) bernama Sri Raja Padmi. Beliau di tasbihkan sebagai Dewi Pradjaparamitha dalam Slamet Mulyono (1979) menyebutkan bahwa candi ini di bangun pada masa pemerintahan Hayam Wuruk $(1359$ - $1389 \mathrm{M})$ dengan nama Pradjnaparamithapuri. Ibu Hayam wuruk adalah tokoh wanita yang diduga bernama Tri Buana Tungga Dewi yang memerintah Majapahit pada tahun $1328-1350$.

\section{B. Teknologi Pembuatan Bata Merah}

Bata merah merupakan bahan bangunan yang terbuat dari tanah liat yang diolah ( di buat adonan), di bentuk, dikeringkan dan kemudian di bakar pada suhu tertentu sampai tanah liat berubah warna menjadi merah. Pemanfaatan bata merah ini banyak ditemukan pada situs- situs penelitian arkeologi terutama dari masa klasik sampai pada masa kolonial. Bata merah ini tergolong bahan bangunan yang mudah pecah jika di lihat dari bahan baku dan teknologi pembuatannya. Pada masa klasik bata merah ini banyak dipergunakan sebagai bahan bangunan untuk keperluan upacara keagamaan seperti candi ataupun tempat pemukiman (rumah tempat tinggal), sedangkan pada masa islam sampai pada masa kolonial bata merah ini banyak dipergunakan untuk membuat mesjid ataupun benteng. Bata merah sebagai bahan bangunan mempunyai sifat-sifat yang hampir sama dengan sifat-sifat tembikar yaitu tidak mudah hancur atau lebur serta melapuk menjadi tanah walaupun tertimbun di dalam tanah dalam jangka waktu panjang dengan kondisi lingkungan yang memungkinkan untuk terjadinya proses pelapukan.

Bata merah sebagai salah satu unsur bangunan yang sangat penting ternyata telah dipergunakan secara luas oleh masyarakat di nusantara sejak dahulu. Pemanfaatan bata merah ini pada masa lalu digunakan sebagai bangunan hunian yang mempunyai fungsi utama sebagai rumah tempat tinggal, disampng untuk bangunan non hunian berupa bangunan suci (tempat pemujaan) atau bentuk struktur lain seperti bendungan dan terowongan air. Luasnya pemanfaatan bata sebagai unsur bangunan mungkin disebabkan karena faktor ketersediaan sumber daya alam yang ada. Bahan baku untuk pembuatan bata merah hanya berupa tanah liat sehingga sangat mudah mendapatkan di sekitarnya jika dibandingkan bahan bangunan lainnya seperti batu. Selain dari 
kemudahan memperoleh bahan baku mungkin faktor lainnya yang menjadi bahan pertimbangan adalah dari segi kemudahan dalam penyusunan bangunan. Hal ini terjadi karena bata merah telah mempunyai bentuk yang teratur dan tertentu sesuai dengan kebutuhan, seangkan jika menggunakan bahan bangunan dari batu tenaga dan biaya yang diperlukan untuk membuat bentuk dan ukuran tertentu memerlukan biaya yang lebih tinggi.

Dalam pembuatan bata merah dengan kualitas yang baik maka terlebih dahulu dilakukan pemilihan bahan baku yaitu berupa tanah liat yang mempunyai kandungan silikat tinggi serta sedikit mengandung senyawa-senyawa organik. Disamping itu ukuran butir juga harus kecil dan sama, tanah liat yang dipergunakan untuk membuat bata merah biasanya mempunyai kualtas yang lebih rendah jika dibandingkan dengan bahan baku untuk membuat tembikat. Tanah liat yang sudah disiapkan kemudian di buat adonan dengan cara di injak-injak sambil menambahkan air sedikit demi sedikit serta membuang batu-batu krakal dan krikil, sampah-sampah organik ( akar-akar, ranting-ranting, daun-daun) yang ikut serta. Jika di dalam bahan baku bata banyak tedapay sampah-sampah organik atau batu-batu krakal ini maka permukaan bata yang dihasilkan menjadi sangat kasar dan pada saat pembakaran selesai banyak tedapat pori-pori. Di daerah tertentu dalam pembuatan adonan ini sudah ada yang mempergunakan teknologi yang lebih tinggi yaitu berupa mesin tetapi prinsip pengerjaannya hampir sama. Untuk beberapa jenis tanah liat pengerajin dengan kondisi tanah tertentu ada yang menambahkan beberapa temper seperti pasir atau sekam padi atau dua jenis tanah liat yang berbeda di campur menjadi satu. Penambahan temper ini menggunakan perbandingan tertentu dengan tujuan untuk memperbaiki kualitas tanah liat dan mempermudah dalam pengerjaan.

Tanah liat dengan campuran temper yang sesuai setelah siap kemudian di cetak menggunakan cetakan khusus untuk membuat bata. Cetakan ini biasanya terbuat dari kayu dan mempunyai ukuran panjang, lebar dan tebal tersendiri di sesuaikan dengan kebutuhan dan untuk tiap daerah biasanya mempunyai ukuran khusus, untuk pengerajin tertentu ada yang menambahkan merk atau kode produksinya pada bagian bawahnya dengan tujuan untuk memperkenalkan atau ciri khas hasil produksinya. Bata merah yang dipergunakan untuk bangunan yang ditemukan pada masa klasik biasanya mempunyai ukuran yang lebih besar jika dibandingkan dengan bata yang ditemukan pada masa kolonial dan masa sekarang. Sebelum memasukan tanah adonan ke dalam cetakan maka pada bagian dasar cetakan terlebih dahulu ditaburi abu atau pasir halus, hal ini dimaksudkan untuk mempermudah pelepasan antara bata yang sudah terbentuk rapi dengan cetaknnya. Bata yang sudah di lepas dari cetakannya ini kemudian dikeringkan baik dengan cara diangin-anginkan atau menggunakan panas matahari dan setelah kering baru di bakar sampai bata ini berwarna merah. 
Proses pembakaran ini ada dua yaitu pembakaran di alam terbuka (pembakaran terbuka) dan menggunakan tungku. Dalam pembakaran di alam terbuka ini jerami atau sekam padi di susun rapi pada tempat yang sudah di pilih, kemudian bata di susun sedemikian rupa sehingga di sela-sela bata ini dapat di beri bahan bakar sehingga pembakaran merata. Setelah bata di susun rapi maka dari bagian atas di tambahkan bahan bakar yang dipergunakan dan kemudian di bakar. Banyaknya bahan bakar yang dipergunakan serta waktu yang diperlukan untuk membakar disesuaikan dengan ukuran dan jumlah bata yang di bakar. Pembakaran dihentikan setelah bata ini berwarna merah menyala dan rata. Sedangkan pembakaran dengan menggunakan tungku maka pengerajin membuat tungku besar dan bata kemudian di susun pada bagian atasnya. Bahan bakar yang dipergunakan dalam proses pembakaran ini biasanya berupa kayu bakar di campur dengan sekam padi. Bahan bakar yang dipergunakan dalam pembakaran dengan menggunakan tungku ini biasanya lebih banyak jika dibandingkan dengan pembakran di alam terbuka. Pembakaran dihentikan setelah bata terbakar secara sempurna, jika pembakaran tidak sempurna maka warna bata tidak akan merah rata tetapi akan ada warna- warna hitam atau kecoklatan baik pada bagian luar maupun bagian dalam. Dengan membandingkan proses pembakarannya maka bata yang di bakar menggunakan tungku biasanya mempunyai kualitas pembakaran yang lebih tinggi.. Hal ini dapat terjadi karena sumber api dan besarnya energi yang dihasilkan oleh bahan bakar lebih tinggi karena sumber panas terpokus pada mulut tungku sehingga panas yang dihasilkan lebih banyak yang di serap oleh bata. Sedangkan jika pembakaran di lakukan di alam terbuka maka banyak energi panas yang dihasilkan menguap keluar karena tidak difokuskan pada satu titik. Energi panas ini berasal dari reaksi antara karbon (C) dengan oksigen $\mathrm{O}_{2}$ yang menghasilkan karbon dioksida $\left(\mathrm{CO}_{2}\right)$ selain energi panas, reaksi yang terjadi adalah:

$$
\mathrm{C}+\mathrm{O}_{2}-\cdots \mathrm{CO}_{2}+\mathrm{E} \text { (api) }
$$

Sedangkan bahan-bahan organik lain seperti unsur Hidrogen $(\mathrm{H})$ akan bereaksi membentuk uap air $\left(\mathrm{H}_{2} \mathrm{O}\right)$, Nitrogen $(\mathrm{N})$ akan berubah menjadi nitrida $\left(\mathrm{N}_{2}\right)$ dan belerang atau sulpida (S) akan membentuk $\mathrm{SO}_{2}$

Bata yang telah terbakar secara sempurna kemudian di tunggu sampai dingin, setelah dingin bata ini di susun kembali dan di pilih serta di pilah bata yang utuh atau ada yang patah. Dalam penyusunan awal bata sebelum di bakar harus diperhatikan karena ini akan mempengaruhi hasil pembakaran, selain itu bata sebelum di bakar harus di pastikan benar-benar kering di samping pemilihan bahan baku. 


\section{nalisis dan Pembahasan}

\section{a. Metode dan Hasil Analisis}

1 Dalam penelitian ini sampel yang dianalisis sebanyak tiga buah yang berasal dari Candi Gayatri yaitu :

1. Bata dari bagian pondasi dengan ukuran $(\mathrm{p} \times 1 \times \mathrm{t})=93 \times 23 \times 5 \mathrm{~cm}$

2. Bata dari bagian pondasi dengan ukuran $(\mathrm{p} \times \mathrm{l} \times \mathrm{t})=50 \times 20 \times 5 \mathrm{~cm}$

3. Bata dari bagian badan dengan ukuran $(\mathrm{p} \times 1 \times \mathrm{t})=33 \times 20 \times 5 \mathrm{~cm}$

Ketiga sampel ini dilakukan analisis sifat-sifat fisik dan unsur kimianya, analisis sifatsifat fisik yang dilakukan untuk mengetahui teknologi pembuatan bata pada masa itu yang meliputi : porositas, serapan air, berat jenis, suhu pembakaran dan mengamati ada tidaknya penggunaan temper dalam hal ini temper yang berasal dari sekam padi atau jerami. Analisis ini dilakukan di laboratorium Pusat Penelitian Arkeologi, dimana penentuan porositas, serapan air, berat jenis dilakukan dengan cara membandingkan dengan menggunakan antara berat kering dengan berat setelah mengalami penetrasi dengan menggunakan air dingin selama 24 jam. Selain membandingkan dengan berat ini juga dilakukan pembandingan dengan berat hasil penimbangan secara hydrostatis dan berat basah. Untuk mengetahui suhu bata pada masa itu dilakukan uji ulang pembakaran dengan menggunakan alat mufle furnance di mana sampel bata di buat potongan-potongan kecil sebanyak sembilan buah untuk setiap sampel. Sampel ini dimasukkan ke dalam mufle furnance sedangkan satu buah dipergunakan sebagai sampel blanko (standar). Kemudian mulai suhu $350{ }^{\circ} \mathrm{C}$ diamati apakah terjadi perubahan warna dengan sampel blanko, pengamatan ini terus dilakukan pada setiap kenaikan suhu $50^{\circ} \mathrm{C}$ sampai pada suhu terjadinya perubahan warna jika dibandingkan dengan warna aslinya (sampel blanko). Jika sudah terjadi perubahan warna maka pembakaran dihentikan dan pada suhu itulah diperkirakan bata tersebut mengalami pembakaran.

Analisis unsur dilakukan dengan menggunakan metode volumetri (titrasi), colorimetri (absorpsi sinar tampak dari larutan sampel), gravimetri (pemisahan unsur yang di cari berdasarkan pengendapan, endapan yang terbentuk kemudian di bakar (dipijarkan) sampai mencapai bentuk molekul yang di cari dalam hal ini silikat dalam bentuk $\mathrm{SiO}_{2}$. Hasil analisis sifat-sifat fisik dan unsur kimia ini dapat dilihat pada tabel 1.1 dan 1.2.

Tabel 1. Hasil Analisis Sifat-sifat Fisik Sampel Bata dari Candi Gayatri

\begin{tabular}{|l|l|l|l|l|l|c|}
\hline No. & Bagian Candi & Porositas & Serapan air & Berat jenis & Suhu & Temper \\
\hline 1. & Pondasi bawah & $30,1 \%$ & $16,9 \%$ & $2,1 \mathrm{gr} / \mathrm{cm}^{3}$ & $700^{\circ} \mathrm{C}$ & - \\
\hline 2. & Pondasi atas & $36,3 \%$ & $19,5 \%$ & $2,4 \mathrm{gr} / \mathrm{cm}^{3}$ & $650{ }^{\circ} \mathrm{C}$ & - \\
\hline 3. & Badan & $39,9 \%$ & $22,8 \%$ & $2,3 \mathrm{gr} / \mathrm{cm}^{3}$ & $650^{\circ} \mathrm{C}$ & + \\
\hline
\end{tabular}


Sebelum melakukan analisis maka semua sampel bata terlebih dahulu dibersihkan dari segala kotoran (tanah yang menempel) dengan cara di sikat baru kemudian dikeringkan dalam oven pada suhu $105{ }^{\circ} \mathrm{C}$ sampai berat konstan (tetap). Dalam melakukan analisis sifat-sifat fisik ini tidak menggunakan bahan- bahan kimia tetapi hanya menggunakan beberapa peralatan laboratorium seperti timbangan elektrik, timbangan hydrostatik, oven, mufle furnance, dan beberapa alat gelas lainnya. sedangkan dalam melakukan analisis unsur-unsur kimia banyak diperlukan bahanbahan kimia seperti: asam nitrat $\left(\mathrm{HNO}_{3}\right)$, asam sulfat $\left(\mathrm{H}_{2} \mathrm{SO}_{4}\right)$ dan asam klorida $(\mathrm{HCl})$. Ketiga asam kuat ini sangat diperlukan terutama dalam peleburan sampel bata karena dalam analisis ini menggunakan metode peleburan basah. Sedangkan bahan-bahan kimia lain yang diperlukan yaitu: beberapa indikator (penolfetealin), etanol $\left(\mathrm{CH}_{3} \mathrm{CH}_{2} \mathrm{OH}\right)$, kalium hidroksida $(\mathrm{KOH})$, beberapa zat pengkompleks seperti fenantrolin, EDTA, dan zat-zat kimia lainnya yang berfungsi untuk mengatur kondisi larutan sampel. Setiap analisis unsur kimia tertentu akan memberikan serapan yang maksimum pada alat spektrofotometer sinar tampak pada derajad keasaman yang berbeda. Dalam analisis unsur kimia dengan metode spektrofotometer sinar tampak maka larutan sampel yang tidak berwarna maka di buat berwarna dengan cara menambahan zat kimia tertentu. Jika tidak terbentuk warna maka larutan sampel ini tidak dapat terabsorbsi. Sedangkan peralatan yang diperlukan adalah spektrofotometer kolorimeter, buret, mufle furnance, oven timbangan analitik, corong, erlenmeyer dengan beberapa ukuran, pipet ukur dengan beberapa ukuran, gelas kimia dengan beberapa ukuran, botol timbang dan alat-alat gelas lainnya yang umum dipergunakan di laoratorium.

Tabel 2. Hasil Analisis Komposisi Unsur Kimia Sampel Bata dari Candi Gayatri

\begin{tabular}{|l|l|c|c|c|c|c|c|}
\hline No. & Bagian Candi & $\begin{array}{c}\mathrm{SiO}_{2} \\
(\%)\end{array}$ & $\begin{array}{c}\mathrm{CaO} \\
(\%)\end{array}$ & $\begin{array}{c}\mathrm{MgO} \\
(\%)\end{array}$ & $\begin{array}{c}\mathrm{Fe} \\
(\%)\end{array}$ & $\begin{array}{c}\mathrm{Al}_{2} \mathrm{O}_{3} \\
(\%)\end{array}$ & $\begin{array}{c}\text { LOI } \\
(\%)\end{array}$ \\
\hline 1. & Pondasi bawah & 80 & 1,4 & 1,4 & 0,05 & 10,0 & 3,5 \\
\hline 2. & Pondasi atas & 76 & 1,4 & 2,2 & 0,03 & 14,7 & 2,4 \\
\hline 3. & Badan & 78 & 1,9 & 2,2 & 0,05 & 7,5 & 7,3 \\
\hline
\end{tabular}

Keterangan:
1. $\mathrm{SiO}_{2}=$ Silikat dioksida
2. $\mathrm{CaO}=$ Kalsium oksida
3. $\mathrm{MgO}=$ Magnesium Oksida
4. $\mathrm{Fe}=$ Unsur besi
5. $\mathrm{Al}_{2} \mathrm{O}_{3}=$ Almunium trioksida
6. LOI $=$ Uji hilang bakar.

\section{b. Pembahasan}

Dengan melihat hasil analisis beberapa sampel bata penyusun Candi Gayatri dari bagian pondasi sampai pada bagian badan candi maka terdapat beberapa perbedaan. Perbedaan ini dapat dilihat pada hasil analisis sifat-sifat fisik (tabel 1.1) yaitu pada 
porositas, serapan air, suhu pembakaran serta penambahan temper ( dalam hal ini sekam padi atau jerami). Sedangkan dari hasil analisis komposisi unsur kimia ( tabel 1.2) terdapat perbedaan pada unsur silikat $\left(\mathrm{SiO}_{2}\right)$, kalsium oksida $(\mathrm{CaO})$, almunium oksida $\left(\mathrm{Al}_{2} \mathrm{O}_{3}\right)$ serta besarnya kandungan LOI (uji hlang bakar). Besarnya porositas dan serapan air pada pondasi bagian bawah, pondasi bagian atas sampai pada bata pada bagian badan candi memperlihatkan hasil yang semakin tinggi. Keadaan ini menunjukan bata pada bagian pondasi sampai pada bagian badan semakin ke atas mempunyai pori-pori dan serapan air yang semakin besar. Suhu pembakaran pada pondasi bagian bawah mencapai $700{ }^{\circ} \mathrm{C}$, suhu pembakaran bata pada pondasi bagian atas dan bagian badan lebih rendah yaitu mencapai $650^{\circ} \mathrm{C}$. Suhu pembakaran yang tinggi pada bata yang ditemukan pada bagian pondasi ini sangat membantu dalam hal peningkatan kualitas bata terutama akan memperbesar kekerasan, memperkecil porositas yaitu $30,1 \%$ jika dibandingkan bata yang lain yang mempunyai porositas yaitu $36,3 \%$ dan $39,9 \%$. Serapan air untuk bata bagian pondasi juga paling kecil yaitu $16,9 \%$ jika dibandingkan bata pada bagian pondasi bagian atas dan badan candi masing-masing $19,5 \%$ dan $22,8 \%$. Bahan baku bata pada bagian pondasi baik pondasi bagian bawah dan atas tidak mempergunakan temper sekam padi atau jerami. Bata merah yang dipergunakan pada bagian badan candi banyak ditemukan adanya penambahan temper dari sekam padi. Sekam padi ini mempunyai berat (beban) yang lebih kecil jika dibandingkan dengan penambahan temper dari pasir atau grog. Sekam padi merupakan senyawa organik di mana unsur karbonnya jika terkena panas akan berubah menjadi senyawa karbon dioksida dan senyawa-senyawa lain yang sebagian besar menguap seperti uap air, sulpida dan nitrida. Sedangkan temper pasir jika terkena panas maka unsur silikanya akan meleleh dan mengisi ruang-ruang kosong bata sehingga akan memberikan sifat yang lebih keras pada bata dan memperkecil sifat porositas dan serapan airnya.

Ditemukannya sekam padi pada bata penyusun candi Gayatri maka sudah dapat dipastikan daerah di sekitar Candi Boyolangu ini sebelum pembuatan candi sudah membudidayakan tanaman padi sebagai bahan pangan. Pemanfaatan sekam padi pada bata penyusun candi ini juga mengindikasikan bahwa pada masa itu teknologi pembuatan bata merah dan penyusunan candi sudah dimiliki oleh masyarakat pemuja candi ini. Padi merupakan tanaman budidaya yang memerlukan lahan yang cukup subur untuk dapat tumbuh dan menghasilkan (berproduksi) secara optimal, sehingga dapat dipastikan pada masa lalu daerah di sekitar candi ini juga sangat subur. Dengan ditemukannya sekam padi ini maka selain mengindikasikan daerah yang subur maka masyarakat pendukung candi ini juga pada masa itu sudah mengenal beras atau nasi sebagai bahan makanan utama. Kesuburan daerah ini mungkin merupakan salah satu alasan mengapa masyarakat pada masa itu mendirikan bangunan candi di daerah Boyolangu ini. Berat jenis suatu benda dapat dipergunakan untuk mngetahui penggolongan mineral dalam hal ini mineral pembentuk bata penyusun candi. Untuk 
ketiga sampel bata penyusun candi ini mempunyai berat jenis tidak berbeda jauh yaitu $2,1 \mathrm{gr} / \mathrm{cm}^{3}-2,4 \mathrm{gr} / \mathrm{cm}^{3}$ dan semua tergolong mineral ringan.

Disamping analisis sifat-sifat fisik maka untuk mengetahui tinggi rendahnya kualitas artefak tanah liat termasuk bata penyusun bangunan candi gayatri ini maka dilakukan analisis komposisi unsur kimia. Dari hasil analisis unsur-unsur kimia seperti pada tabel 1.2 maka diketahui kandungan unsur silikat dalam bentuk $\mathrm{SiO}_{2}$ paling besar terdapat pada sampel bata yang ditemukan pada pondasi bagian bawah yaitu $80 \%$ jika dibandingkan dengan sampel bata pada bagian pondasi bagian atas dan bagian badan candi yaitu $76 \%$ dan $78 \%$. Kandungan silikat yang tinggi serta mempunyai suhu pembakaran yang tinggi maka akan menyebabkan banyaknya unsur-unsur kimia dalam bahan baku bata yang ditemukan pada pondasi bagian bawah sudah mengalami pelelehan (mencapai titik leleh) sehingga mempunyai kualitas yang paling tinggi. Suhu titik leleh setiap unsur kimia yang terdapat dalam bahan baku bata ini berbeda antara satu unsur dengan unsur yang lainnya. Lelehan unsur silikat ini akan dapat memberikan daya rekat yang lebih tinggi antar unsur penyusun bata sehingga bata menjadi lebih keras. Daya rekat ini dapat terjadi karena pada suhu yang tinggi banyak unsur-unsur kimia penyusun bata yang meleleh dan mengisi ruang-ruang kosong. Hasil uji hilang bakar (LOI) paling besar ditemukan pada sampel bata bagian badan yaitu $7,3 \%$, keadaan ini dapat terjadi karena dalam pengolahan bahan baku ditambahkan temper sekam padi. Sekam padi merupakan senyawa organik sehingga pada saat terjadi pembakaran banyak yang hilang dan menguap. Keadaan ini menyebabkan bata mempunyai lebih banyak ruang-ruang kosong sehingga porositas dan serapan air menjadi lebih besar. Kondisi seperti ini mengakibatkan bata yang dihasilkan lebih ringan jika dibandingkan dengan bata yang ditemukan pada bagian pondasi. Unsur kalsium banyak ditemukan pada bata bagian badan, unsur ini jika bercampur dengan unsur silikat akan dapat memberikan pengaruh terhadap kekuatan bata sehingga bangunan ini menjadi lebih kokoh dan kuat. Pencampuran dua unsur kimia (silikat dan kalsium karbonat) setelah mengalami pembakaran akan lebih kuat dan tahan pada saat menerima gangguan dari alam baik itu gangguan biotik ( jamur, lumut atau berbagai mikroorganisme) maupun abiotik ( panas matahari, air hujan atau perbedaan cuaca yang sangat tinggi). Jika bahan bangunan (bata) mempunyai porositas dan serapan air yang tinggi maka akan lebih mudah mengalami kerusakan atau pelapukan terutama karena pengaruh lingkungan. Pori-pori dalam bata ini akan dimanfaatkan oleh beberapa mikroorganisme dan tumbuhan tingkat rendah lainnya sebagai media tempat hidupnya, sehingga mahluk hidup ini hidup dan berkembang di dalam pori-pori ini dan memanfaatkan bata ini sebagai sumber makannnya. Selain dari faktor biotik ini pengaruh faktor abiotik juga sangat berbahaya terutama adanya garam-garam atau logam-logam berat yang menenpel pada bata atau pori-porinya yang berasal dari polusi udara atau terbawa oleh air hujan. Air Hujan banyak sekali mengandung asam-asam atau garam-garam yang dapat menempel pada bata ini. Kualitas bata yang tidak baik ini dan ditambah lagi dengan kondisi lingkungan yang 
tidak mendukung maka akan semakin cepat merusak bangunan candi. Keadaan ini jika dibiarkan terus menerus maka proses pelapukan akan lebih cepat jika dibandingkan dengan bata yang mempunyai porositas dan serapan air yang lebih kecil.

Dari hasil analisis laboratorium ini maka dapat diketahui bahwa pada jaman dahulu masyarakat penyusun Candi Gayatri di samping memperhatikan kualitas bahan baku bata, juga sangat memperhatikan kontruksi penyusunan bangunan. Pemilihan bahan baku dan pemilihan penyusunan kontruksi bangunan ini ditujukan untuk memperkuat pondasi candi sebagai daya dukung terhadap ketahanan bangunan. Dengan melihat hasil analisis laboratorium ini maka bata pada bagian pondasi mempunyai kualitas yang paling tinggi (paling keras, pori-pori dan serapan air paling kecil, kandungan silikat paling tinggi serta suhu pembakaran paling tinggi) jika dibandingkan dengan bata pondasi bagian atas dan bagian badan. Disamping hal ini penambahan temper juga mempengaruhi kualitas dari bata, bata pondasi bagian bawah tidak mempunyai temper yang terbuat dari sekam padi, sedangkan bata pada pondasi bagian atas dan bagian badan memperlihatkan adanya penambahan temper sekam padi. Tidak ditambahkannya sekam padi sebagi temper pada bata bagian pondasi dimaksudkan agar bangunan pada bagian pondasi khususnya paling bawah mempunyai kekuatan yang paling tinggi, guna untuk dapat menahan beban yang ada pada bagian atas bangunan candi. Sedangkan penambahan sekam padi pada bata bagian atas (badan) dimaksudkan untuk mengurangi beban pada bagian pondasi sehingga bagian ini tidak terlalu berat menahan beban yang ada di bagian atasnnya.

Pembangunan Candi Gayatri pada masa lalu sangat memperhatikan kualitas dan kontruksi bangunan sehingga sampai saat ini masih berdiri kokoh walaupun hanya menggunakan bahan dasar batu bata merah yang terbuat dari tanah liat. Teknologi penyusunan bangunan seperti pada Candi Gayatri ini masih dibudayakan oleh masyarakat Indonesia bahkan dunia internasional dimana di dalam membuat sebuah bangunan kontruksi pada bagian dasar (pondasi) harus mempunyai kualitas yang lebih tinggi (bahan lebih kuat) jika dibandingkan dengan bahan yang dipergunakan diatasnya. Bahan pondasi bangunan yang kuat diharapkan akan menghasilkan suatu bangunan yang kuat dan tahan terhadap terhadap berbagai faktor lingkungan yang merugikan dan dapat mempercepat proses pelapukan.

\section{$\mathbf{P}$} enutup

Bata merah sebagai unsur bangunan sudah di kenal oleh nenek moyang Bangsa beberapa situs arkeologi maka pemanfaatan bata merah sebagai unsur utama bangunan banyak ditemukan pada masa klasik (baik untuk keperluan profan maupun religi). Di daerah Jawa Timur khususnya di Kabupaten Tulung Agung bata merah ditemukan selain sebagai unsur bangunan candi juga banyak ditemukan dalam bentuk struktur- 
struktur pondasi yang dimungkinkan merupakan sisa-sisa pemukiman. Candi Gayatri merupakan salah satu bangunan candi di daerah ini yang mempergunakan bata merah sebagai unsur utama bagunannya di samping mempergunakan bahan bangunan lainnya. Dengan ditemukannya bata sebagai bahan bangunan pada masa lampau (klasik) membuktikan bahwa teknologi pembuatan bata merah sudah di kenal oleh masyarakat Indonesia sejak masa itu. Teknologi pembuatan bata merah ini ternyata tetap membudaya di masyarakat nusantara sampai saat ini, bahkan bata merah merupakan unsur bangunan yang mempunyai kualitas yang tinggi sampai saat ini sehingga mempunyai nilai ekonomis yang tinggi juga. Dengan kemajuan teknologi maka pada saat ini sudah berkembang bahan bangunan menyerupai bata merah tetapi tidak memerlukan proses pembakaran. Masyarakat tertentu menyebutnya dengan nama batako, yang menggunakan bahan baku dari tanah liat (bahan khusus) dan campuran antara semen dan pasir dengan perbandingan tertentu. Bentuk bahan ini juga mirip dengan bata merah, dan pembuatnnya juga di cetak dengan ukuran sesuai dengan kebutuhan. Antara bata merah dan batako ini masing-masing mempunyai kelebihan dan kekurangan sebagai bahan untuk membuat bangunan, tetapi semuanya mempunyai nilai ekonomis yang tinggi.

Hasil analis laboratoris membuktikan bahwa pada jaman dahulu dalam pembangunan Candi Gayatri sudah memperhatikan kontruksi dan kualitas bahan baku bangunan untuk mendapatkan bangunan candi yang kuat, kokoh dan tahan terhadap gangguan karena faktor lingkungan. Kuat dan kokohnya bangunan candi yang menggunakan bahan utama bata merah tergantung dari kualitas bahan bakunya dan teknologi pembuatnnya. Bata merah yang dipergunakan pada bangunan candi Gayatri ini mempunyai kandungan silikat $\left(\mathrm{SiO}_{2}\right)$ dan senyawa kapur $\left(\mathrm{CaCO}_{3}\right)$ yang tinggi. Gabungan kedua senyawa ini membuat bata merah menjadi kuat dan kokoh, jika terjadi sebaliknya maka bata merah yang dihasilkan menjadi sangat rapuh dan mudah patah. Suatu bangunan dapat berdiri kokoh dan tahan lama jika pondasi suatu bangunan di buat dengan bahan yang mempunyai kualitas yang tinggi jika dibandingkan dengan kualitas bahan bangunan yang ada di atasnya.

Dengan kemajuan dan perkembangan teknologi maka dalam pembuatan pondasi bangunan juga mengalami peningkatan kualitas tergantung dari ketersediaan sumber bahan yang ada di sekitarnya. Pada beberapa tinggalan arkeologi terutama pada bangunan candi ada yang memanfaatkan batu kali sebagai bahan pondasi. Pada saat ini dalam pembuatan pondasi bangunan baik berupa candi, perumahan, jembatan atau jalan layang ada yang mempergunakan beton yang terbuat dari kerangka besi dicampur dengan pasir, semen dan pecahan batu kali. Hal ini mempunyai tujuan yang sama yaitu untuk memperkuat daya tahan terhadap bangunan atau beban yang ada di atasnya. Dalam pembangunan Candi Gayatri pondasi bagian bawah mempunyai kualitas yang paling tinggi, semakin ke atas kualitasnya semakin berkurang serta mempunyai berat yang berkurang. Bata yang ditemukan pada bagian atas 
mempergunakan bahan temper dari sekam padi, sehingga beratnya berkurang dan beban yang ditanggung oleh bagian pondasi semakin berkurang. Data penelitian ini akan lebih lengkap jika sampel pada bagian puncak juga di analisis, hal ini dimaksudkan untuk mengetahui apakah bata pada bagian puncak mempunyai beban yang lebih kecil ( dilihat dari besar kecilnya pori-pori yang ada serta pemanfaatan senyawa organik sebagai bahan temper). Teknologi penyusunan bangunan seperti pada Candi Gayatri sampai sekarang dipergunakan sebagai slogan oleh beberapa masyarakat Indonesia yang berbunyi: "Pondasi yang Kuat akan Menghasilkan Bangunan yang Kuat". Slogan ini masih berlaku di masyarakat terutama dalam usaha membuat bangunan, tetapi dalam kehidupan sehari-hari di masyarakat juga memanfaatkan slogan ini untuk membangun sumber daya manusia .

\section{KEPUSTAKAAN}

Amelia, dkk, 1998. Laporan Penelitian Arkeologi Tulungagung VI, Jakarta. Puslit Arkenas (tidak terbit)

Bambang Sumadio, dkk, 1986. Sejarah Nasional Indonesia II, Jakarta, Balai Pustaka.

Soeroso, Mp 1989. Laporan Penelitian Arkeologi Tulungagung I, Jakarta, Puslit Arkenas (tidak terbit)

Sudarti Prijono, 1995a, Analisis Unsur terhadap Gerabah-gerabah Kuno dari Beberapa Situs Arkeologi. Dalam Jurnal Penelitian Balai Arkeologi Bandung, No, 1/April/1995, Bandung, Balai Arkeologi.

1995 b, Pengukuran Porositas dan Serapan Air Fragmen Gerabah Temuan Situs Batubrak, Provinsi lampung. Dalam Jurnal Penelitian Balai Arkeologi Bandung, No. 1/April/1995, Bandung, Balai Arkeologi.

Tim Studi Perencanaan, 1995. Laporan Penelitian Studi Perencanaan Pengembangan tempat- tempat Bersejarah dan Purbakala, di kabupaten Tulungagung, Provinsi Jawa Timur, Balai Arkeoloi Yogyakarta.

Tim Penelitian, 2000, Laporan Penelitian rkeologi di DAS Berantas, Kabupaten

Tulungagung, Provinsi Jawa Timur, Bidang Arkeometri, Puslit Arkenas (Tidak terbit).

Herman, V.J, 1989. Pedoman Konservasi Koleksi Museum, Proyek Pembinaan Permuseuman, Jakarta, Direktorat Jendral Kebudayaan, Depdikbud. 